\title{
ANALISA KINERJA PERUSAHAAN DALAM RANGKA PERSIAPAN SPIN OFF UNIT USAHA SYARIAH PT. ASURANSI ADIRA DINAMIKA
}

\author{
Eko Suryawadi \\ Institut Teknologi \& Bisnis Ahmad Dahlan Jakarta \\ Email : eko.suryawadi@gmail.com
}

\begin{abstract}
ABSTRAK
Penelitian ini bertujuan untuk menganalisa tingkat kesiapan Unit Usaha Syariah PT. Asuransi Adira Dinamika,Tbk dengan menggunakan metode penelitian deskriptif kuantitatif. Data yang dikumpulkan adalah data sekunder diperoleh dari laporan keuangan tahun 2016-2019. Pengukuran kinerja dilakukan dengan menentukan persentase rasio pencapaian perspektif keuangan pada indikatorindikatornya sebagai dasar pencapaian target keuangan dalam persiapan spin off. Hasil penelitian menunjukkan bahwa kinerja Unit Usaha Syariah PT. Asuransi Adira Dinamika,Tbk pada tahun 2016 -2019 secara umum dalam kondisi sangat sehat dan memenuhi syarat untuk melakukan spin off sesuai Undang-Undang No. 40 Tahun 2014 dan POJK No 67/POJK.05/2016.
\end{abstract}

Kata kunci : Asuransi Syariah, Kinerja Perusahaan, Spin Off.

\begin{abstract}
This study aims to analyze the level of readiness of the Sharia Business Unit of PT. Asuransi Adira Dinamika, Tbk by using quantitative descriptive research methods. The data collected is secondary data obtained from the 2016-2019 financial statements. Performance measurement is carried out by determining the percentage of the financial perspective achievement ratio on the indicators as the basis for achieving financial targets in preparation for the spin off. The results showed that the performance of the Sharia Business Unit of PT. Asuransi Adira Dinamika, Tbk in 2016 - 2019 was generally in a very healthy condition and met the requirements for a spin off in accordance with Law no. 40 of 2014 and POJK No. 67/POJK.05/2016.
\end{abstract}

Keywords : Sharia Insurance, Company Performance, Spin Off. 


\section{PENDAHULUAN}

Mengacu pada regulasi yang dikeluarkan pemerintah yaitu UndangUndang No 40 Tahun 2014 dan Peraturan Otoritas Jasa Keuangan No. 67 Tahun 2016 yang mengatur kebijakan Spin Off Unit Usaha Asuransi Syariah yang isinya "Perusahaan Asuransi dan Perusahaan Reasuransi wajib melakukan pemisahan unit usaha syariah menjadi perusahaan Asuransi Syariah atau perusahaan Reasuransi Syariah apabila dana tabarru dan dana investasi peserta telah mencapai paling sedikit 50\% (lima puluh persen) dari total nilai dana Asuransi. Dana tabarru dan dana investasi peserta pada perusahaan induknya atau 10 (sepuluh) tahun sejak diundangkannya Undang-Undang No. 40 tahun 2014 tentang perasuransian. Artinya unit usaha asuransi syariah wajib spin off pada tahun 2024. Dan pada tahun 2020 ini unit usaha syariah wajib membuat rencana kerja tentang kebijakan spin off. Kebijakan spin off ini mendorong industri asuransi syariah makin berkembang dan kompetitif dalam peningkatan pangsa pasar asuransi syariah.

Tetapi pada kenyataannya banyak unit usaha syariah belum siap untuk melakukan pemisahan dengan perusahaan induknya. (Ghoni \& Arianty, 20121). Salah satu unit usaha syariah yang akan melakukan kebijakan yang diatur Undangundang No. 40 tahun 2014 dan Peraturan Otoritas Jasa Keuangan No. 67 tahun 2016 adalah PT. Asuransi Adira Dinamika Unit Syariah atau PT. Asuransi Adira Dinamika Unit Syariah. PT. Asuransi Adira Dinamika Unit Syariah (AIS) merupakan Unit Usaha Syariah dari PT. Asuransi Adira Dinamika, Tbk (Adira Insurance), didirikan pada tanggal 5 Maret 2004 berdasarkan Surat Keputusan Menteri Keuangan Republik Indonesia No. KEP-092/KM.6/2004 guna memenuhi kebutuhan masyarakat Indonesia akan produk asuransi Syariah. Di tahun 2019, PT. Asuransi Adira Dinamika Unit Syariah mengelola total Dana Tabarru sebesar Rp. 229 Milyar dengan jumlah peserta aktif 1,3 juta polis. PT. Asuransi Adira Dinamika, Tbk sendiri sejak
November $2019 \quad 80 \%$ (delapan puluh persen) sahamnya telah dimiliki Zurich Insurance Group. Sebagai Unit Usaha Syariah, Adira Insurance Syariah harus mempersiapkan rencana kerja untuk melakukan spin off sebagaimana diwajibkan oleh Undang-undang No. 4 tahun 2014 dan Peraturan Otoritas Jasa Keuangan paling lambat pada tahun 2020 berdasarkan PJOK No. 67 tahun 2016.

Dengan latar belakang ingin mengetahui persiapan dan proses spin off unit usaha syariah PT. Asuransi Adira Dinamika, Tbk, peneliti menuangkannya dalam bentuk jurnal dengan judul "Analisa Kinerja Perusahaan Dalam Rangka Persiapan Spin Off Unit Usaha Syariah PT Asuransi Adira Dinamika, Tbk"

\section{TINJAUAN PUSTAKA}

\section{Asuransi Syariah}

Perjanjian antara penanggung yang mengikatkan diri kepada seorang tertanggung dan jika mengalami kerugian maka dia akan menerima premi asuransi pengganti adalah pengertian dari asuransi. Asuransi Syariah dalam fatwa MUI (Dewan Syariah Nasional MUI, 2001) artinya sebagai berikut: "Fatwa No 21/DSN-MUI/X/2001 Asuransi Syariah adalah usaha saling melindungi dan tolongmenolong di antara sejumlah pihak melalui investasi dalam bentuk asset dan atau tabarru yang memberikan pola pengembalian untuk menghadapi resiko tertentu melalui akad (perikatan) yang sesuai dengan syariah". (Suma \& Amin, 2020)

\section{Analisa Laporan Keuangan}

Analisis laporan keuangan adalah suatu alat yang digunakan untuk membuat suatu keputusan antara lain mengenai rencana-rencana perluasan usaha, penanamman modal pencarian sumbersumber dana operasional perusahaan. (Yusuf, 2020)

\section{Kinerja}

Kinerja (performance) adalah gambaran mengenai tingkat pencapaian 
pelaksanaan suatu kegiatan atau program atau kebijakan dalam mewujudkan sasaran, tujuan, misi, dan visi organisasi yang tertuang dalam strategic planning suatu organisasi. Kinerja adalah fungsi dari kemampuan organisasi untuk mendapatkan dan mengelola sumber daya dalam beberapa cara yang berbeda untuk mengembangkan keunggulan kompetitif (Nurlatifah \& Mardian, 2016).

\section{Spin Off}

Pasal 1 ayat 12 Undang-Undang PT. No. 40 tahun 2007 tentang Perseroan Terbatas, spin off dikatakan sebuah pemisahan yang di definisikan sebagai berikut :

"Perbuatan hukum yang dilakukan oleh perseroan untuk memisahkan usaha yang mengakibatkan seluruh aktiva dan pasiva perseroan beralih karena hukum kepada 2 (dua) perseroan atau lebih atau sebagian aktiva dan pasiva perseroan beralih karena hukum kepada 1 (satu) perseroan atau lebih spin off merupakan bentuk pelepasan yang berakibat pada divisi atau bagian perusahaan menjadi perusahaan yang mandiri, dengan melepaskan satu unit bisnis, seperti anak perusahaan berdiri sendiri”. (Kuncoro \& Yulianto, 2018)

\section{Dasar Hukum Kebijakan Spin Off Unit Usaha Syariah}

Dalam jurnal ilmiah (Dasopang, 2019) mengemukan bahwa kebijakan spin off itu tertuang dalam Undang-Undang No. 40 Tahun 2014 pasal 87 ayat 1 yang berbunyi "Dalam hal perusahaan asuransi atau perusahaan reasuransi memiliki unit usaha syariah dengan nilai dana tabarru dan dana investasi peserta telah mencapai paling sedikit 50\% (lima puluh persen) dari total nilai dana asuransi dana tabarru, dan dana investasi peserta pada perusahaan induknya atau sepuluh tahun sejak diundangkannya Undang-Undang ini, perusahaan asuransi atau perusahaan reasuransi tersebut wajib melakukan pemisahan unit syariah tersebut menjadi perusahaan asuransi syariah atau perusahaan reasuransi syariah." Selanjutnya dalam jurnal ilmiah (Nurhidayat, 2021) menerangkan ketentuan lebih lanjut mengenai pemisahan unit usaha syariah dan sanksi bagi perusahaan asuransi dan perusahaan reasuransi yang tidak melakukan pemisahaan unit usaha syariah sebagaimana dimaksud pada ayat (1) diatur dalam peraturan otoritas jasa keuangan tepatnya pada pasal 17 dan 18. Yaitu Peraturan Otoritas Jasa Keuangan no 67/ POJK. 05/2016, pasal 17 mengenai pemisahan unit usaha syariah.

\section{PENELITIAN TERDAHULU}

1. Jurnal ilmiah yang berjudul Strategi Spin Off Bagi Pengembangan Keuangan Syariah: Tinjauan Kasus Asuransi Syariah (Nasution, 2019) menyatakan bahwa strategi pemisahan (spin-off) bagi pengembangan asuransi syariah. Berdasarkan penyelidikan literature review, didapatkan bahwa spin-off sangat diperlukan untuk mengembangkan unit syariah agar lebih mandiri dalam menjalankan bisnisnya. Kebermanfaatan lainnya adalah adanya restrukturisasi perusahaan melalui pemecahan unit usaha baru yang berdampak pada tingkat profitabilitas yang lebih baik. Banyak kasus empiris membuktikan bahwa pemegang saham sengaja melakukan spin-off dan berdampak secara langsung dengan tingkat keuntungan yang lebih besar. Beberapa dampak tersebut menempatkan spin-off sebagai strategi untuk mengembangkan nilai ekuitas perusahaan. Meski demikian, kasus spin-off pada asuransi syariah juga perlu dilakukan secara hati-hati, mengingat spin-off mampu menimbulkan biaya transaksi, terutama dalam hal penyediaan SDM dan permodalan asuransi syariah yang tinggi. Maka dari itu, spin-off membutuhkan penguatan kelembagaan, pelanggan Unit Usaha Syariah yang handal, dan penguatan SDM, agar perusahaan yang dipisahkan dapat mengatur dan mengelola perusahaan secara independen.

2. Dalam jurnal berjudul Analisis Peluang dan Tantangan Pelaksanaan Kewajiban 
Spin-Off Unit Usaha Syariah Menjadi Bank Umum Syariah Studi Kasus PT. BNI Syariah (Putra et al, 2019) menunjukan bahwa proses spin-off pada BNI Syariah didorong oleh pentingnya melakukan spin-off sebagai alternatif strategi menghadapi perkembangan bisnis yang semakin ketat. Adapun faktor-faktor yang mendukung proses terjadinya spin-off antara lain :

a. Faktor eksternal berupa dukungan dari regulator dan pemerintah.

b. Faktor internal meliputi ketentuan corporate plan BNI Syariah yang sejak awal berdirinya merencanakan spin-off.

Sedangkan tantangan yang dihadapi adalah sosialisasi nasabah, pemisahan neraca laba rugi dan perpajakan, pemisahan IT dan membentuk culture bank baru.

3. Penelitian berjudul Analisis Kinerja Keuangan Unit Syariah PT. Asuransi Jiwa Manulife Indonesia Dalam Rangka Spin Off (Krinsawarman et al, 2016). Berdasarkan hasil penelitian Unit Syariah Manulife Indonesia belum siap melaksanakan spin off karena belum memenuhi persyaratan yang ditetapkan. Kinerja keuangannya cukup baik, kinerja dalam pengelolaan dana tabarru' dan dana investasi peserta perlu ditingkatkan karena hasil underwriting ratio diakhir tahun tidak mencapai $40 \%$ dan hasil perbandingan nilai pada komponen investasi dana peserta yang berlebihan pada instrumen saham syariah tidak memenuhi ketentuan.

4. Tesis berjudul Analisis Balance Scorecard dalam menilai kerja PT Asuransi Ramayana Unit Syariah untuk melakukan spin off paling lambat tahun 2024 (Bustomi, 2019). Hasil penelitian menunjukkan bahwa kinerja PT Asuransi Ramayana Unit Syariah dari perspektif keuangan pada tahun 2016 2018 secara umum baik, pada rasio solvabilitas dan rasio aktivitas lebih baik dibandingkan dengan ukuran baku perusahaan asuransi di Indonesia. Namun jika dilihat dari rasio likuiditas dan rentabilitas maka masih di bawah nilai baku. Kinerja perusahaan dari perspektif pelanggan dan perspektif pembelajaran dan pertumbuhan pada tahun 2016 - 2018 sudah baik. Kinerja dari perspektif proses bisnis internal sudah baik, dimana persentase telah memenuhi standar Peraturan No. 072/POJK.05/2016. Namun dalam hal kesesuaian Undang-Undang No. 40 Tahun 2014 belum sepenuhnya dilaksanakan. Jadi, dapat disimpulkan bahwa PT. Asuransi Ramayana Unit Syariah dalam proses menuju persiapan untuk melakukan pemisahan (spin off) perusahaan serta didukung dengan analisis 4 perspektif balance scorecard yang mendapatkan hasil baik.

\section{METODE PENELITIAN}

Penelitian ini menggunakan analisis deskriptif yaitu suatu kegiatan untuk menyusun, mengklasifikasikan, menafsirkan serta menginterpretasikan data sehingga memberikan suatu gambaran tentang permasalahan yang diteliti. Menurut Sujarweni (2014) penelitian kuantitatif adalah jenis penelitian yang menghasilkan penemuan-penemuan yang dapat dicapai (diperoleh) dengan menggunakan prosedurprosedur statistik atau cara lain dari kuantifikasi (pengukuran). Metode penelitian ini deskriptif kuantitatif dengan menggunakan analisis rasio menghitung kinerja perusahaan berkaitan dengan laporan keuangan perusahaan periode tahun 2016-2019 yang telah di audit dan dipubikasikan. Rumus rasio keuangan disusun dalam PSAK No. 28 Tahun 2011 tentang perlakuan Akuntansi Asuransi Kerugian dikutip dari jurnal ilmiah (Nurfadila et al, 2015) sebagai berikut :

1. Solvency Ratio. Solvency Margin Ratio menggambarkan kemampuan keuangan perusahaan dalam memenuhi kewajiban resiko. Batas normal rasio kecukupan solvabilitas minimal 33,3\%.

2. Rasio Profitabilitas 
a. Underwriting

merepresentasikan

Ratio

tingkat

underwriting yang didapat dan digunakan untuk mengukur tingkat keuntungan operasional dari kerugian operasional membandingkannya dengan pendapatan premi.

b. Rasio Beban Klaim menunjukkan klaim perusahaan. Batas normal maksimum dari rasio klaim adalah $100 \%$.

c. Rasio Komisi mempresentasikan biaya komisi yang dikeluarkan perusahaan untuk mendapatkan pendapatan.

d. Rasio Pengembalian Investasi

Rasio Pengembalian Investasi berfungsi mengukur seberapa banyak pencapaian investasi yang dilakukan.

3. Rasio Likuiditas
a. Rasio
Likuiditas
Aset mempresentasikan berapa besar kemampuan perusahaan dalam memenuhi kewajiban dengan bantuan aset yang yang dimiliki.

b. Investment to Technical Reserve Ratio digunakan untuk mengetahui sejauh mana kewajiban teknis yang diciptakan perusahaan asuransi tercermin dalam investasi.

4. Rasio Stabilitas Premi

a. Rasio Pertumbuhan Premi menggambarkan besar kenaikan premi pada tahun berjalan dibandingkan tahun sebelumnya, apabila peningkatannya terlalu rendah tidak mencapai batas normal atau negatif dimasukkan ke dalam kelompok di luar batas normal.

b. Rasio Retensi Diri menunjukkan tingkat penjagaan perusahaan dalam menanggung resiko.

5. Rasio Teknis. Rasio Kewajiban Teknis menggambarkan tingkat kecukupan cadangan yang diperlukan dalam menghadapi kewajiban yang timbul dari penutupan resiko. Ada beberapa yang menyebut kewajiban teknis dengan cadangan teknis. Tidak ada batas normal untuk rasio ini, tetapi perlu diperhatikan tinggi rendahnya rasio ini apakah memberikan indikasi yang baik atau tidak. Apabila terlalu rendah dikhawatirkan cadangan teknis yang dibentuk perusahaan tidak mencukupi untuk membayar kewajibannya di masa mendatang. Sebaliknya bila terlalu tinggi menunjukkan portofolio usaha kurang merata.

Berdasarkan Peraturan Nomor 72/POJK.05/2016 tingkat kesehatan asuransi syariah dikutip dalam karya ilmiah (Bustomi, 2019), indikator yang digunakan adalah sebagai berikut:

a. Perusahaan setiap tahun wajib menetapkan target tingkat solvabilitas dengan mempertimbangkan profil resiko perusahaan minimum $120 \%$ dari DTMBR.

b. Penyisihan teknis, meliputi cadangan premi, cadangan atas premi yang belum polis atau tertanggung.

c. Ekuitas, perusahaan asuransi wajib memiliki ekuitas paling sedikit sebesar Rp. 25.000.000.000,- (seratus miliar rupiah).

d. Dana Jaminan, perusahaan wajib membentuk dana jaminan paling rendah $20 \%$ dari ekuitas minimum atau dengan $1 \%$ premi neto ditambah $0,25 \%$ premi reasuransi.

\section{Identifikasi dan Pengukuran Variabel}

Identifikasi variabel pada penelitian ini menunjukkan keterkaitan antara hubungan variabel dependen dengan variabel independen. Variabel dependen pada penelitian ini adalah harga saham dan variabel independen manajemen resiko sedangkan kinerja keuangan perusahaan sebagai variabel mediasi. Variabel-variabel yang digunakan pada penelitian ini yakni : 
Credit risk, Liquidity Risk, Capital Adequacy Ratio, Operational Risk, Market Risk, dan Coorporate Finance Performance dalam hal ini yang diukur dengan Return On Asset (ROA) dan Return On Equity (ROE).

\section{HASIL PENELITIAN}

Analisis laporan keuangan, khusus mencurahkan perhatian pada perhitungan rasio agar mudah dievaluasi keadaan keuangan suatu perusahaan baik masa yang lalu, masa kini dan masa yang akan datang yang merupakan cara yang paling umum dipakai untuk menganalisa laporan keuangan, dengan kata lain untuk mengukur kekuatan dan kelemahan keuangan suatu perusahaan dapat dianalisa melalui rasio keuangan yang dinyatakan dalam artian relatif maupun absolut untuk menjelaskan hubungan tertentu antara faktor yang satu dengan faktor yang lainnya yang terdapat di dalam laporan keuangan. (Muhani et al, 2015)

\section{Tabel 1. Analisa Rasio Keuangan Unit Usaha Syariah PT Asuransi Adira} Dinamika,Tbk

\begin{tabular}{|c|c|c|c|c|c|c|c|}
\hline \multirow{2}{*}{ No } & \multirow{2}{*}{ Rasio } & \multirow{2}{*}{ Batas Normal } & \multicolumn{4}{|c|}{ Tahun } & \multirow{2}{*}{ Rata-rata } \\
\hline & & & 2016 & 2017 & 2018 & 2019 & \\
\hline 1 & $\begin{array}{l}\text { Solvency Margin } \\
\text { Ratio }\end{array}$ & $\begin{array}{c}\text { Minimal } \\
33,3 \%\end{array}$ & $135 \%$ & $139 \%$ & $224 \%$ & $356 \%$ & $214 \%$ \\
\hline 2 & Underwriting Ratio & Minimal 40\% & $12 \%$ & $17 \%$ & $21 \%$ & $21 \%$ & $18 \%$ \\
\hline 3 & Rasio Beban Klaim & $\begin{array}{c}\text { Maksimal } \\
100 \% \\
\end{array}$ & $35 \%$ & $41 \%$ & $38 \%$ & $37 \%$ & $38 \%$ \\
\hline 4 & Rasio Komisi & - & $43 \%$ & $43 \%$ & $45 \%$ & $48 \%$ & $45 \%$ \\
\hline 5 & $\begin{array}{l}\text { Rasio Pengembalian } \\
\text { investasi }\end{array}$ & Minimal 15\% & $2 \%$ & $2 \%$ & $2 \%$ & $2 \%$ & $2 \%$ \\
\hline 6 & Rasio Likuiditas Aset & $\begin{array}{c}\text { Maksimal } \\
120 \% \\
\end{array}$ & $63 \%$ & $58 \%$ & $43 \%$ & $37 \%$ & $50 \%$ \\
\hline 7 & $\begin{array}{l}\text { Investment to } \\
\text { Technical Reserve } \\
\text { Ratio }\end{array}$ & - & $320 \%$ & $306 \%$ & $250 \%$ & $253 \%$ & $282 \%$ \\
\hline 8 & $\begin{array}{l}\text { Rasio Pertumbuhan } \\
\text { Premi }\end{array}$ & Minimal 23\% & $114 \%$ & $27 \%$ & $-43 \%$ & $-33 \%$ & $16 \%$ \\
\hline 9 & Rasio Retensi Diri & - & $54 \%$ & $54 \%$ & $49 \%$ & $45 \%$ & $51 \%$ \\
\hline 10 & $\begin{array}{l}\text { Rasio Kewajiban } \\
\text { Teknis }\end{array}$ & - & $67 \%$ & $76 \%$ & $115 \%$ & $148 \%$ & $102 \%$ \\
\hline
\end{tabular}

Sumber : Data diolah (2021)

Kinerja keuangan Unit Usaha Syariah PT. Asuransi Adira Dinamika dari tahun 2016 sampai dengan tahun 2019 berdasarkan analisis rasio keuangan sudah sangat baik dan cenderung stabil. Solvency margin ratio sudah sangat baik dengan memperoleh hasil di atas batas minimal, dan cenderung mengalami kenaikan setiap tahunnya. Underwriting Ratio walaupun masih di bawah batas minimal, tetapi tetap mengalami surplus setiap tahun, artinya perusahaan masih mengalami keuntungan usaha.
Rasio beban klaim sangat baik karena berada jauh di bawah batas maksimal, perusahaan mampu membayar klaim yang diajukan peserta. Rasio komisi stabil di angka $40 \%$ sesuai perhitungan teknis komisi ke tenaga penjual dikisaran $40 \%$ dari kontribusi yang diterima, dengan memberikan komisi atau ujroh kepada tenaga penjual dan mitra bisnisnya target perolehan kontribusi atau premi akan tercapai. Rasio pengembalian investasi walaupun masih dibawah batas minimal tetap ada keuntungan investasi, hal ini dikarenakan perusahaan investasi pada 
instrumen keuangan syariah yang resikonya kecil seperti deposito syariah dan surat berharga lainnya. Rasio likuiditas aset dan retensi diri sangat bagus dan stabil, rasio likuiditas aset sangat jauh dari batas maksimal. Investment to technical reserve ratio mengalami penurunan artinya cadangan teknis yang terbentuk pada investasi semakin kecil. Dan rasio kewajiban teknis juga mengalami peningkatan, cadangan teknis juga makin besar. Dengan kinerja keuangan yang sangat baik dan stabil akan menunjang persiapan spin off unit usaha syariah.

Tabel 2. Tingkat Kesehatan Menurut POJK No 72/POJK.05/2016 (Dalam Jutaan)

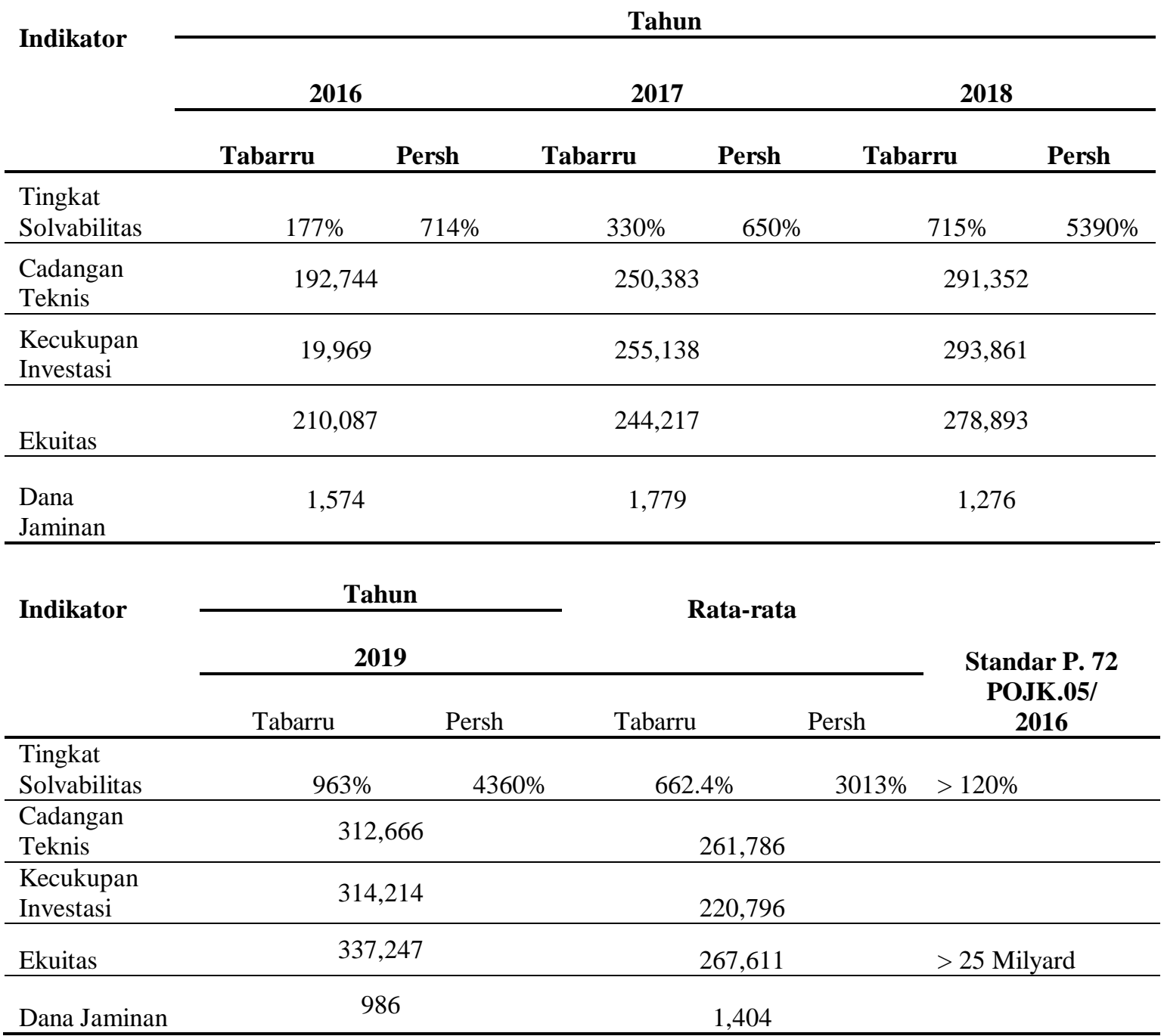

Sumber: Data diolah (2021)

Berdasarkan tabel 2 nilai rata-rata tingkat tingkat solvabilitas selama tahun 2016-2019 dana tabarru sebesar 963\% dan dana perusahaan sebesar $4360 \%$, hal ini menunjukkan kondisi perusahaan sangat sehat karena diatas angka ideal Peraturan No. 72/POJK.05/2016 sebesar $120 \%$. Sementara itu, perusahaan telah melakukan cadangan teknis yang meliputi cadangan premi, Cadangan Atas Premi Yang Belum Masuk Pendapatan (CAPYBMP). Dan cadangan klaim dari tahun 2016-2019 dengan rata-rata sebesar Rp. 261,786,000,000. Serta kecukupan investasi perusahaan meliputi cadangan teknis, hutang pembayaran klaim dan 
hutang lain kepada pemegang polis atau tertanggung dengan rata-rata $\mathrm{Rp}$. 265,726,000,000, ini menunjukkan bahwa perusahaan telah melaksanakan Peraturan No. 72/POJK.05/2016, maka perusahaan dapat dikatakan dalam kondisi sangat sehat. Dalam jumlah ekuitas perusahaan selama tahun 2016-2019 sebesar Rp. 267,611,000,000. Jumlah ekuitas tersebut memenuhi standar yang ditetapkan Peraturan No. 72/POJK.05/2016 minimal sebesar Rp. 25.000.000.000,- Maka dapat dikatakan dalam kondisi sehat. Adapun dana jaminan perusahaan selama tahun 2016-2019 memiliki rata-rata sebesar Rp.1,404,000,000, ini menggambarkan bahwa perusahaan telah melaksanakan Peraturan No. 72/POJK.05/2016, maka dapat dikatakan dalam kondisi sehat. Dengan kondisi kesehatan tersebut Unit Usaha Syariah siap untuk spin off di tahun 2021.

\section{HASIL DAN PEMBAHASAN}

Tabel 3. Kinerja Keuangan Unit Usaha Syariah

\begin{tabular}{|c|c|c|c|c|}
\hline Indikator & Batas Normal & \multicolumn{2}{|c|}{ Realisasi } & Penilaian \\
\hline Solvency Margin Ratio & Minimal 33,3\% & \multicolumn{2}{|c|}{$214 \%$} & Di atas batas minimal \\
\hline Rasio Beban Klaim & Maksimal $100 \%$ & \multicolumn{2}{|c|}{$38 \%$} & Di bawah batas maksimal \\
\hline Rasio Komisi & - & \multicolumn{2}{|c|}{$45 \%$} & Masih normal aturan OJK \\
\hline $\begin{array}{l}\text { Rasio Pengembalian } \\
\text { investasi }\end{array}$ & Minimal $15 \%$ & \multicolumn{2}{|c|}{$2 \%$} & Masih ada keuntungan $2 \%$ \\
\hline Rasio Likuiditas Aset & Maksimal $120 \%$ & \multicolumn{2}{|c|}{$50 \%$} & Perusahaan Likuid \\
\hline Rasio Pertumbuhan Premi & Minimal 23\% & \multicolumn{2}{|c|}{$16 \%$} & Dibawah minimal \\
\hline Rasio Retensi Diri & - & \multicolumn{2}{|c|}{$51 \%$} & $51 \%$ kontribusi neto \\
\hline \multirow[t]{2}{*}{ Rasio Kewajiban Teknis } & - & \multicolumn{2}{|c|}{$102 \%$} & Cadangan teknis $102 \%$ \\
\hline & & & & Dalam Jutaan \\
\hline \multirow{3}{*}{ Indikator } & Standar P. 72 & \multirow{2}{*}{\multicolumn{2}{|c|}{ Rata-rata }} & \multirow{3}{*}{ Penilaian } \\
\hline & POJK.05/ & & & \\
\hline & 2016 & Tabarru & Persh & \\
\hline Tingkat Solvabilitas & $>120 \%$ & $963 \%$ & $4360 \%$ & Sesuai target di POJK \\
\hline Cadangan Teknis & & & 312,666 & Sesuai target di POJK \\
\hline Kecukupan Investasi & & & 314,214 & Sesuai target di POJK \\
\hline Ekuitas & $>25,000$ & & 337,247 & Sesuai target di POJK \\
\hline Dana Jaminan & & & 5,615 & Sesuai target di POJK \\
\hline
\end{tabular}

Sumber: Data diolah (2021)

Dari tabel 3 rasio-rasio keuangan solvency margin ratio jauh di atas batas manimal $33,3 \%$ yaitu $214 \%$ ini menggambarkan perusahaan sangat sehat, Rasio Beban klaim di bawah batas maksimal $100 \%$ yaitu $38 \%$ artinya pendapatan kontribusi bias membiayai klaim yang terjadi. Rasio likuiditas aset di bawah batas maksimal $120 \%$ yaitu 50\% artinya bahwa asetnya bisa membayar kewajiban $50 \%$ dari aset, perusahaan sangat sehat. Rasio Pertumbuhan Premi di bawah batas normal $23 \%$ yaitu $16 \%$ artinya penurunan pendapatkan kontribusi selama tahun 2018 dan 2019 karena kondisi ekonomi pada saat itu. Rasio komisi dan rasio kewajiban teknis tidak ada batas normal tapi perusahaan wajib mengontrol sesuai dengan aturan-aturan Otoritas Jasa Keuangan. Dari tabel diatas pemenuhan peraturan tentang kesehatan asuransi syariah bahwa Unit Usaha 
Syariah PT. Asuransi Adira Dinamika dalam kategori sehat dengan tingkat solvabilitas Tabarru $963 \%$ dan tingkat solvabilitas dana perusahaan $4360 \%$. Kesehatan perusahaan menjadi dasar dalam rangka pemenuhan kewajiban yang diatur dalam peraturan yang mengatur tentang perizinan perusahaan asuransi, dan terutama mengenai pemisahan Unit Usaha Syariah sebagaimana diwajibkan dalam perasuransian. Dan hasil analisa persiapan Unit Usaha Syariah dapat disimpulkan sebagai berikut.

1. Menurut Pasal 6 ayat 3. Perusahaan Asuransi Syariah harus memiliki Modal Disetor pada saat pendirian paling sedikit sebesar Rp. 100.000.000.000,00 (seratus miliar rupiah). Dari aturan ini Unit Usaha Syariah PT. Asuransi Adira Dinamika sudah siap karena memiliki Ekuitas $337,247,000,000$ untuk penambahan modal disetor.
2. Menurut Pasal 7 ayat 1. Berbunyi bahwa "Pada saat pengajuan izin usaha, Perusahaan harus memiliki Dana Jaminan paling sedikit 20\% (dua puluh persen) dari Modal Disetor minimum yang dipersyaratkan sebagaimana dimaksud dalam Pasal 6 ayat (1) sampai dengan ayat (4)". Unit Usaha Syariah PT. Asuransi Adira Dinamika memiliki dana jaminan 5,614,847,500 pada saat ini, $20 \%$ dari modal disetor.

3. Pasal 14 ayat 1 . Mengatakan bahwa "Perusahaan Asuransi Syariah hasil konversi harus memiliki Ekuitas pada saat konversi paling sedikit sebesar Rp100.000.000.000,00 (seratus miliar rupiah)". PT. Zurcih General Takaful Indonesia (Dahulu PT. Zurich Insurance Indonesia) memiliki Ekuitas 300 Milyar terdapat dalam laporan keuangan 2019.

Tabel 4. Ikhtisar Keuangan

PT. Zurich Insurance ndonesia

Dalam Milyaran

\begin{tabular}{|c|c|c|}
\hline & 2018 & 2019 \\
\hline Total Investasi & 404.2 & 363.4 \\
\hline Total Aset & 818.5 & 831.8 \\
\hline Ekuitas Dana Perusahaan & 302.5 & 332.0 \\
\hline Rasio Batas Tingkat Solvabilitas & $289 \%$ & $347 \%$ \\
\hline
\end{tabular}

4. Pasal 17 ayat 1. Menyebutkan bahwa

"Perusahaan Asuransi dan

Perusahaan Reasuransi wajib melakukan Pemisahan Unit Syariah menjadi Perusahaan Asuransi Syariah atau Perusahaan Reasuransi Syariah apabila Dana Tabarru' dan dana investasi peserta telah mencapai paling sedikit 50\% (lima puluh persen) dari total nilai Dana Asuransi, Dana Tabarru', dan dana investasi peserta pada perusahaan induknya atau 10 (sepuluh) tahun sejak diundangkannya Undang-Undang No
40 Tahun 2014 tentang Perasuransian". Dengan aturan ini mematuhi 10 tahun sejak diundangkan, untuk 50\% dari dana perusahaan induk, belum memenuhi syarat karena aset perusahaan induk sudah di atas 5 Trilyun, sedangkan Unit Usaha Syariah memiliki aset 800 Milyar, aset di atas perusahaan asuransi syariah penuh yang sudah eksis seperti Takaful Umum dan Chubb Syariah.

5. Pasal 19 ayat 1. Bahwa "Ekuitas pada saat pendirian Perusahaan Asuransi 
Syariah hasil Pemisahan sebagaimana dimaksud dalam Pasal 18 ayat (1) huruf a paling sedikit sebesar Rp. 50.000.000.000,00 (lima puluh miliar rupiah)". Untuk ekuitas dari Unit Usaha Syariah di atas 300 Milyar dan perusahaan hasil konversi masih memiliki ekuitas juga di atas 300 Milyar, dari sisi ekuitas perusahaan siap untuk memenuhi kewajibannya.
Analisa Laporan Laba Rugi sebelum Spin Off dan Asumsi Laba Rugi pasca Spin Off Unit Usaha Syariah PT. Asuransi Adira Dinamika,Tbk

Untuk mengetahui adanya pengaruh kinerja perusahaan terhadap proses spin off ini dapat kita lihat dari asumsi beban usaha pada laporan keuangan dengan pendapatan kontribusi yang sama. Berikut asumsi beban usaha pada saat sebagai Unit Usaha Syariah dan Perusahaan Asuransi Syariah penuh.

Tabel 5 Laporan Laba Rugi Unit Usaha Syariah PT. Asuransi Adira Dinamika,Tbk Berdasarkan Laporan Keuangan

\begin{tabular}{lcl}
\hline \multicolumn{1}{c}{ Dekripsi } & Nominal & Keterangan \\
\hline Kontribusi Bruto & $210,779,000,000$ & \\
\hline $\begin{array}{l}\text { Ujroh Pengelola/ Pendapatan } \\
\text { Operasional }\end{array}$ & $100,857,000,000$ & \\
\hline Laporan Laba Rugi & & \\
\hline Pendapatan & $100,857,000,000$ & \\
\hline Pendapatan Operasional (ujroh) & $33,000,000$ & \\
\hline Perubahan Penyisihan Ujroh & & \\
\hline $\begin{array}{l}\text { Pendapatan pembagian Surplus } \\
\text { Underwriting }\end{array}$ & $17,787,000,000$ & \\
\hline Pendapatan Investasi & $29,752,000,000$ & Dibayarkan Ke Agen \\
\hline Jumlah Pendapatan & & Asuransi \\
\hline Beban & & Benefit lain-lain \\
\hline Beban Komisi & $59,429,000,000$ & Biaya Operasional UUS \\
\hline Ujroh dibayar & $1,059,000,000$ & termasuk gaji \\
\hline Beban Usaha & $25,178,000,000$ & \\
\hline Jumlah Beban Usaha & $86,160,000,000$ & \\
\hline Laba Usaha & $62,269,000,000$ & \\
\hline
\end{tabular}

\section{Sumber : PT. Asuransi Adira Dinamika, Tbk (2020)}

Dari tabel diatas dapat 59,923,000,000 adalah komisi yang disimpulkan bahwa pada saat menjadi diberikan kepada agen penjual produk Unit Usaha Syariah, dengan kontribusi asuransi, ujroh dibayar Rp 1,059,000,000 bruto Rp. 210,779,000,000 akan diberikan untuk benefit-benefit lainnya, mendapatkan ujroh yang dijadikan dan terakhir beban usaha sebesar Rp. pendapatan operasional Rp. 25,178,000,000 adalah beban operasional $100,857,000,000$. Ditambah pendapatan usaha asuransi yang dilakukan Unit Usaha penyisihan perubahan ujroh, pendapatan Syariah diantaranya gaji karyawan. pembagian surplus underwriting dan Dengan jumlah beban Rp. pendapatan investasi jumlah pendapatan 86,160,000,000, perusahaan mendapatkan menjadi Rp. 148,429,000,000. Pada Laba Usaha sebesar Rp. 62,269,000,000. Beban, ada beban komisi Rp. Pada laporan laba rugi ini, peneliti akan 
membadingkan beban usaha pada saat masih menjadi Unit Usaha Syariah beban usaha Rp. 25,178,000,000, beban usaha ini terdapat unsur biaya gaji dan biaya operasinal untuk karyawan dari level
Dewan Pengawas Syariah dan Kepala Divisi sampai ke bawah Unit Usaha Syariah, tidak termasuk Komisaris dan Direksi, karena masih menjadi beban induk perusahaan.

\section{Tabel 6. Asumsi Laporan Laba Rugi Pasca Spin Off Unit Usaha Syariah PT} Asuransi Adira Dinamika,Tbk Berdasarkan Laporan Keuangan

\begin{tabular}{lcc}
\multicolumn{1}{c}{ Dekripsi } & Nominal & Keterangan \\
\hline Kontribusi Bruto & $210,779,000,000$ & \\
\hline Ujroh Pengelola/ Pendapatan & $100,857,000,000$ & \\
Operasional & & \\
\hline Laporan Laba Rugi & & \\
\hline Pendapatan & $100,857,000,000$ & \\
\hline Pendapatan Operasional (ujroh) & $33,000,000$ & \\
\hline Perubahan Penyisihan Ujroh & $17,787,000,000$ & \\
\hline Pendapatan pembagian Surplus & $29,752,000,000$ & Dibayarkan Ke Agen \\
Underwriting & $148,429,000,000$ & Asuransi \\
\hline Pendapatan Investasi & & Benefit lain-lain \\
\hline Jumlah Pendapatan & $59,923,000,000$ & Biaya Operasional UUS \\
\hline Beban & $1,059,000,000$ & \\
Beban Komisi & $40,178,000,000$ & \\
\hline Ujroh dibayar & $101,160,000,000$ & \\
\hline Beban Usaha & $47,269,000,000$ & \\
\hline Jumlah Beban Usaha & & \\
\hline Laba Usaha & & \\
\hline
\end{tabular}

Sumber : PT. Asuransi Adira Dinamika, Tbk (2020)

Dari tabel diatas dengan asumsi laporan keuangan yang sama dapat disimpulkan bahwa pada saat sudah menjadi perusahan asuransi full Syariah, dengan kontribusi bruto $\mathrm{Rp}$. 210,779,000,000 akan mendapatkan ujroh yang dijadikan pendapatan operasional Rp. 100,857,000,000.

Ditambah pendapatan penyisihan perubahan ujroh, pendapatan pembagian surplus underwriting dan pendapatan investasi jumlah pendapatan menjadi Rp. 148,429,000,000. Pada Beban, ada beban komisi Rp. 59,923,000,000 adalah komisi yang diberikan kepada agen penjual produk asuransi, Ujroh dibayar $\mathrm{Rp}$. 1,059,000,000 diberikan untuk benefitbenefit lainnya, dan terakhir beban usaha sebesar Rp. 40,178,000,000 adalah beban operasional usaha asuransi yang dilakukan perusahaan asuransi full Syariah diantaranya gaji karyawan. Dengan jumlah beban Rp. 101,160,000,000, maka perusahaan mendapatkan Laba Usaha berkurang menjadi Rp. 47,269,000,000. Pada laporan laba rugi ini ada perbedaan pada beban usaha dikarenakan apabila perusahaan sudah menjadi perusahaan asuransi syariah penuh dan terpisah dari induk akan memiliki struktur organisasi tersendiri dari komisaris, direksi, dewan pengawas syariah dan beberapa tenaga ahli asuransi kerugian dan tenaga ahli asuransi syariah sebagai syarat menjadi perusahaan asuransi syariah penuh. Dari 2 (dua) tabel tersebut dapat kita ambil penilaian bahwa dengan menjadi perusahaan asuransi penuh, Unit Usaha Syariah PT. Asuransi Adira Dinamika pasca spin off harus minimal sama pendapatan kontribusi (premi)nya apabila ingin tetap mendapatkan laba. Adapun 
penambahan beban usaha setelah spin off adalah sebagai berikut :

1. Adanya beban usaha operasional dan gaji komisaris.

2. Adanya beban usaha operasional dan gaji direksi.

3. Adanya beban usaha operasional dan gaji dewan pengawas syariah.

4. Adanya beban usaha operasional dan gaji tenaga ahli, seperti underwiter, komite audit setingkat direksi.

5. Penambahan sumber daya manusia, insfrastruktur dan IT system yang lepas dari induknya, walaupun bertahap tetap harus dipersiapkan.

Pasca pemisahan (spin off) manajemen harus bisa memproyeksikan target-target sebagai berikut :

1. Pertumbuhan kontribusi (premi).

2. Surplus Underwriting lebih besar dengan menekan beban klaim.

3. Meningkatkan pendapatan investasi

4. Meminimalisir rasio kerugian akibat klaim, rasio komisi yang sesuai tidak melebihi aturan Otoritas Jasa Keuangan dan meminimalisir beban operasional perusahaan dengan efiensi.

Uji ini untuk memastikan apakah ada interkorelasi atau kolinearitas antar variabel independen. Pengujian dilakukan dengan menggunakan sistem eviews dan melihat hasil VIF pada output coefficients, dengan kriteria: Jika VIF > 10, maka terdapat multikolinearitas Jika VIF $<10$, maka tidak terdapat multikolinearitas. Analisa data penelitian ini VIF bernilai kurang dari 10 yakni 0,92 maka artinya tidak terdapat multikolinearitas.

\section{KESIMPULAN}

Unit Usaha Syariah PT Asuransi Adira Dinamika, Tbk sudah siap untuk melakukan pemisahan (spin off) dengan melihat rasio-rasio keuangan dalam kondisi sehat dan perusahaan selalu mendapatkan keuntungan pada 4 (empat ) periode laporan keuangan terutama dari surplus underwriting dan investasi. Dengan tingkat solvabilitas yang sangat sehat dan ekuitas yang dimiliki dapat menjadi tambahan modal disetor sebagai syarat menjadi perusahaan asuransi penuh. Dukungan pemilik saham mayoritas Zurich Gobal dengan mengkonversi PT Zurich Insurance Indonesia menjadi perusahaan asuransi umum syariah sebagaimana amanat Undang-Undang No. 40 Tahun 2014 dan POJK No. 67/POJK.05/2016.

\section{DAFTAR PUSTAKA}

Bustomi, Ahmad Yazid. 2019. Analisis Balance Scorecard dalam menilai kerja PT Asuransi Ramayana Unit Syariah untuk melakukan spin off paling lambat tahun 2024. Tesis. Sekolah Tinggi Ilmu Ekonomi Indonesia.

Dasopang, Nursania, 2019. Tinjauan Hukum Pemisahan (Spin Off) Unit Usaha Syariah Menjadi Perusahaan Asuransi Syariah (Full Fledge). Yuris Prudentia: Jurnal Hukum Ekonomi, 5(1), p. 16-29.

Dewan Syariah Nasional MUI. 2001. Fatwa DSN-MUI No.21/DSNMUI/X/2001 tentang Pedoman Umum Asuransi Syariah, p. 1-7.

Ghoni, Abdul., \& Arianty, Erny. 2021. Perbandingan Tingkat Efisiensi Perusahaan Full-pledged dengan Unit Usaha Asuransi Syariah di Indonesia untuk Mengukur Kesiapan Spin-off. Proceedings IHTIFAZ: Islamic Economics, Finance, and Banking Universitas Ahmad Dahlan, p. 132-148.

Krisnawarman, Andry., Muchtar, Ali Masjono., \& Suhartati, Titi. 2016. 
Analisis Kinerja Keuangan Unit Syariah PT Asuransi Jiwa Manulife Indonesia Dalam Rangka Spin Off. Account; Jurnal Akuntansi, Keuangan dan Perbankan 3(2), p. 446-454.

Kuncoro, Amin., \& Yulianto, Heru. 2018. Kinerja Keuangan Sesudah dan Sebelum Spin Off Unit Usaha Syariah. EQUILIBRIUM : Jurnal Ekonomi Syariah, 6(2), p. 291315.

Muhani, Mustafa., Hapid., \& Safril. 2015. Penilaian Kinerja Keuangan Dengan Analisis Rasio Keuangan Pada Perusahaan Asuransi yang Go Public di Bursa Efek Indonesia (BEI) Tahun 2013. Jurnal Manajemen STIE Muhammadiyah Palopo, 2(1), p.32-43.

Nasution, Lokot Zein. 2019. Strategi Spin Off Bagi Pengembangan Keuangan Syariah: Tinjauan Pada Kasus Asuransi Syariah. Jurnal Dinamika Ekonomi Pembangunan (JDEP), 2(2), p. 213-226.

Nurfadila, Sindi., Hidayat, Raden Rustam., \& Sulasmiyati, Sri. 2015. Analisis Rasio Keuangan dan Risk Based Capital untuk Menilai Kinerja Keuangan Perusahaan Asuransi. Jurnal Administrasi Bisnis (JAB), 22(1), p. 1-9.

Nurhidayat, Tatang. 2021. Peramalan Bisnis Unit Usaha Syariah PT ABC dalam Tantangan Spin Off. Ad-Deenar: Jurnal Ekonomi dan Bisnis Islam, 5(02), p. 231-244.

Nurlatifah, Ai Fitri., \& Mardian, Sepky. 2016. Kinerja Keuangan Perusahaan Asuransi Syariah di Indonesia : Surplus on Contribution. Akuntabilitas :
Jurnal Ilmu Akuntansi 9(1), p. 7396.

Putra, Ari Andika., Qosim, Ahmad Mulyadi., \& Hakiem, Hilman. 2019. Analisis Peluang dan Tantangan Pelaksanaan Kewajiban Spin-Off Unit Usaha Syariah Menjadi Bank Umum Syariah (Studi Kasus PT. BNI Syariah). Al Amwal (Hukum Ekonomi Syariah), 2(1), p. 1-12.

Sujarweni, V. Wiratna. 2014. Metode Penelitian: Lengkap, Praktis, dan Mudah Dipahami. Pustaka Baru Press. Yogyakarta.

Suma, Muhammad Amin., \& Amin, Iim Qo'immudin. 2020. Asuransi Syariah Di Indonesia Telaah Teologis, Historis, Sosiologis, Yuridis dan Futurologis. Amzah. Jakarta.

Yusuf, Yuliana. 2020. Analisis Rasio Keuangan Dalam Menilai Kinerja Keuangan Pada PT Asuransi Jiwa Sinarmas MSIG, Tbk yang terdaftar di Bursa Efek Indonesia. POINT : Jurnal Ekonomi dan Manajemen, 2(2), p. 77-86. 